\title{
The antimicrobial activity of green tea extract against the major food born bacteria
}

\author{
Hadi Mohebalian ${ }^{1 *}$, Soodabeh Alizadeh ${ }^{2}$ \\ ${ }^{1,2}$ Department of Pathobiology, Faculty of Veterinary Medicine, Ferdowsi university of Mashhad, Mashhad, Iran
}

\section{Key Words:}

Food borne bacteria

Green tea

Minimum Inhibitory Concentration (MIC)

Received: 23 May 2016

Accepted: 12 June 2016

Published: 24 June 2016

\begin{abstract}
Food poisoning and infectious diseases caused by food-borne bacteria are a worldwide concern and can also be fatal. Green tea exhibits antibacterial effects against a wide range of bacteria. The objective of this study was to determine the antibacterial effect of different concentrations of green tea extract against some of the major foodborne bacteria. Antibacterial activities of different concentrations of alcoholic and aqueous green tea extract were evaluated against Staphylococcus aureus, E.coli, Kelebsiella pneumonia, and Pseudomonas spp. by the disk diffusion method and the Minimum Inhibitory Concentration (MIC) assay. The inhibition zones of aqueous extract (concentration $20 \mu \mathrm{l}$ ) was 14, 15, 15, $17 \mathrm{~mm}$ for pseudomonas, E.coli, K.pneumoniaand S.aureusrespectively and inhibition zones of alcoholic extract (concentration $20,28 \mu \mathrm{l}$ ) was 16, 21, 15,1 $9 \mathrm{~mm}$ for pseudomonas, E.coli, Kelebsiellaand S.aureusrespectively. The most zone of inhibition was observed against S.aureusand pseudomonas has the least inhibition zone. Ethanolic extract of green tea was more effective as compared to aqueous extract. Green tea extract showed good activity against foodborne bacteria, and Our results suggest that this plant has major antibacterial activity against these bacteria comparable with the standard antibiotic. This characteristic of green tea may be related to its polyphenolic Components.
\end{abstract}

(C) 2016 The Author(s). Published by TAF Publishing.

\section{INTRODUCTION}

Food-borne bacteria are the major cause of disease in many countries [1]. Food poisoning is a food industry concern and can also be fatal. Diseases have varied symptoms include watery or bloody diarrhea, meningitis, chronic renal disorders, immunologic and cardiovascular complications [2]. Considerable 49amount of food is spoiled due to the unavailability of effective preservatives and due to increasing 50 antibiotic resistance of some food borne pathogens [3].

At 2005, World Health Organization has estimated 1.8 million people died of diarrheal diseases 52 and infections related to consumption of contaminated food and water and in 2006 food borne illness 53 outbreaks have been reported in our country [2-4]. Escherichia coli and Pseudomonas spp are the most common causes of diarrhea in developing countries 55 and Staphylococcus aureus and Kelebsiellapeneumoniae are another bacterialagents in the incidence of 56 food poisoning and infections [2]. Despite the range of artificial preservation techniques available these days, The increasing demands for 58natural' foods have evoked the search for alternative antimicrobial elements to killor at least to inhibit 59growth of bacteria to help control the wholesomeness of food [3-5]. Now day

\footnotetext{
${ }^{*}$ Corresponding author: Hadi Mohebalian

${ }^{\dagger}$ Email: mohebalian@um.ac.ir
} 
many antibacterial agents used against infectious diseases have been derived from medicinal 61 plants. In different world area several plants are directly or indirectly used to treat various diseases [6]. Their extracts importance in recent years for varied pharmaceutical and food processing applications [7] for several years the green tea has been subjected to numerous medical and antimicrobial studies.

The Green tea has been originated from China, but it has become associated with many cultures throughout Asia such65as Iran. [8] Green tea contains a variety of enzymes, amino acids, carbohydrates, lipids, sterols andphytochemical 68compounds, such as alkaloids, saponins, tannins, catechin and polyphenols (Sofowara, 1984; Opara, 691992) and dietary minerals so It is rich in various components [10-12]. 70 Moreover, green tea polyphenols have been applied to functional drug and foods for beneficial to human 71 health for its antibacterial antiviral, and antifungal activities [13]. In the present study we evaluated the antimicrobial effects of green tea extract as a new antibacterialmaterial [11]. We hypothesis that green tea extract has selective growth-inhibitory activity against various strains of Escherichia coli, Pseudomonas spp, Staphylococcus aureusandKelebsiella75peneumoniae strains [9].

\section{MATERIALS AND METHOD}

\section{Collection of Plant Samples}

The plant samples were collected from different places at Tehran main market in August-September 8 32014. The collected samples were put in plastic bags and immediately transferred to laboratory.

\section{Bacterial Strains}

This study involves some clinical strains of food borne bacteria as Escherichia coli ATCC 8739 Pseudomonas spp ATCC 15442, Staphylococcus aureusATCC 9144 and Kelebsiellapeneumoniae87PTCC 1290. Pure cultures were refreshed and maintained on nutrient agar slants and kept inincubator 88 overnight at $37^{\circ} \mathrm{C}$ and then stored at $4^{\circ} \mathrm{C}$. 90 Aqueous and ethanolic green tea extracts preparation. The plant leaves were properly washed by distilled water and $100 \mathrm{~g}$ of each green tea materials was grinded with grinder, filtered and then lyophilized under reduced pressure and kept in the dark. For this93work, putting dried material in boiling water and was boiled for $45 \mathrm{~min}$.

What man no. 1 filter paper was used to filtering. The filtrate was heated at $40-50^{\circ} \mathrm{C}$ using water baths, until thick paste is formed. The obtained extract was then lyophilised. The lyophilised extract stored at $4^{\circ} \mathrm{C}$ in refrigerator. The Same stageswere used to ethanolic extract preparation by $95 \%$ ethanolic solvent instead of sterilized distilled water.

\section{Agar-Well Diffusion Assay of Crude Extracts}

The anti-bacterial assay was done on Mueller Hinton agar (Difco) plates by agar well diffusion method. The bacterial inoculum was prepared from overnight-grown cultures $(24 \mathrm{~h})$ in nutrient broth (Difco) with turbidity equivalent to $0.5 \mathrm{McFarland}$ units (approximately $1.2 \times 108 \mathrm{CFU} \mathrm{ml}-1)$. Aliquots $(100 \mu \mathrm{l})$ of inoculums were cultured on agar plates. Sterile discs (diameter of $6 \mathrm{~mm}$ ), were placed at the center of 102 each plate and then the green tea extracts were added on the discs. The plates incubated for $24 \mathrm{~h}$ at $37^{\circ} \mathrm{C}, 103$ and after time duration the zone of bacterial growth inhibition around the disc was measured. If the organism was more or less sensitive to the extract, clear zone of the growth inhibition was appeared around the disc. 


\section{Determination of Minimum Inhibitory Concentration}

The lowest concentration of green tea extract that completely inhibits the growth of the organism was defined as MIC. Bacterial cultures were enriched in nutrient broth for 10 hours at $35^{\circ} \mathrm{C}$. Overnight bacteria were seeded into the tubes containing nutrient broth and the green tea extracts were tested atconcentration 15 and $20 \mu \mathrm{l} / \mathrm{mL}$ and then incubated for $24 \mathrm{~h}$ at $35^{\circ} \mathrm{C}$. Serial broth dilutions method insterile tubes, was done according to Clinical and Laboratory Standards Institute [14].

\section{RESULTS}

\section{Antibacterial Activity of Green Tea Extracts}

The selected standard antibiotic inhibition zone diameter against considered strains is shown in Table 1. All of the strains were sensitive to gentamycin because of inhibitory

TABLE 1. Antibiotic inhibition zone diameter against food borne bacteria

\begin{tabular}{|c|c|c|c|c|}
\hline \multicolumn{4}{|c|}{ Zone Diameter (mm) } & Antibiotic \\
\hline $\begin{array}{l}\text { Staphy- } \\
\text { lococcus } \\
\text { Aureus } \\
\text { ATCC } 9144\end{array}$ & $\begin{array}{l}\text { Klebsiella } \\
\text { PTCC } 1290\end{array}$ & $\begin{array}{l}\text { Pseu- } \\
\text { domonas } \\
\text { Aeruginosa } \\
\text { ATCC } 15442\end{array}$ & $\begin{array}{ll}\text { E.coli } & \text { ATCC } \\
8739 & \end{array}$ & \\
\hline 25 & 22 & 18 & 18 & Gentamycin \\
\hline 29 & $\mathrm{R}$ & $\mathrm{R}$ & $\mathrm{R}$ & Clindamycin \\
\hline 21 & $\mathrm{R}$ & $\mathrm{R}$ & $\mathrm{R}$ & Penicillin \\
\hline $\mathrm{R}$ & $\mathrm{R}$ & $\mathrm{R}$ & $\mathrm{R}$ & Vancomycin \\
\hline 24 & $\mathrm{R}$ & $\mathrm{R}$ & 20 & $\begin{array}{l}\text { Chloram- } \\
\text { phenicol }\end{array}$ \\
\hline
\end{tabular}

TABLE 2 . Antimicrobial activity of aqueous green tea extracts comparable with alcoholic green tea extract

\begin{tabular}{|c|c|c|c|c|}
\hline \multicolumn{4}{|c|}{ Inhibition Zone Diameter } & \multirow[t]{2}{*}{ Extracts } \\
\hline $\begin{array}{l}\text { S.aureus } \\
\text { ATCC } 9144\end{array}$ & $\begin{array}{l}\text { K.pneumo- } \\
\text { nia ePTCC } \\
1290\end{array}$ & $\begin{array}{l}\text { Pseu- } \\
\text { domonas } \\
\text { ATCC } 15442\end{array}$ & $\begin{array}{ll}\text { E.coli } & \text { ATCC } \\
8739 & \end{array}$ & \\
\hline 17 & 15 & 14 & 15 & $\begin{array}{l}\text { Aqueous Ex- } \\
\text { tract } \mu \mathrm{l} 20\end{array}$ \\
\hline 19 & 15 & 16 & 21 & $\begin{array}{l}\text { Alcoholic ex- } \\
\text { tract } \mu \mathrm{l} 20\end{array}$ \\
\hline 20 & 18 & 14 & 16 & $\begin{array}{l}\text { Aqueous ex- } \\
\text { tract } \mu \mathrm{l} 15\end{array}$ \\
\hline 24 & 20 & 17 & 24 & $\begin{array}{l}\text { Alcoholic ex- } \\
\text { tract } \mu \mathrm{l} 15\end{array}$ \\
\hline
\end{tabular}

nature of this antibiotic for aminoglycoside synthesis. Although, the inhibition zone diameter of green tea extracts against selected bacterial at a concentration of $20 \mu \mathrm{l}$ and $15 \mu \mathrm{l}$ of both aqueous and alcoholic extract is shown in Table 2. Antibacterial activity of ethanolic extracts of green tea showed that these bacteria were sensitive to the concentrations of $96 \%$ ethanolic extracts as a control solution which were $12 \mathrm{~mm}, 13 \mathrm{~mm}, 13 \mathrm{~mm}, 14 \mathrm{~mm}$, 125 and $15 \mathrm{~mm}$ for E. coli, Pseudomonas, K.pneumoniaeand S. areas respectively. 


\section{Calculation of MIC}

Antibacterial activity of green tea leaf extract against selected is demonstrated in Table 3. Results showed that MIC of aqueous green tea extract for Pseudomonas and E.coli was

TABLE 3 . MIC and MBC of aqueous and alcoholic green tea extracts on selected bacterial

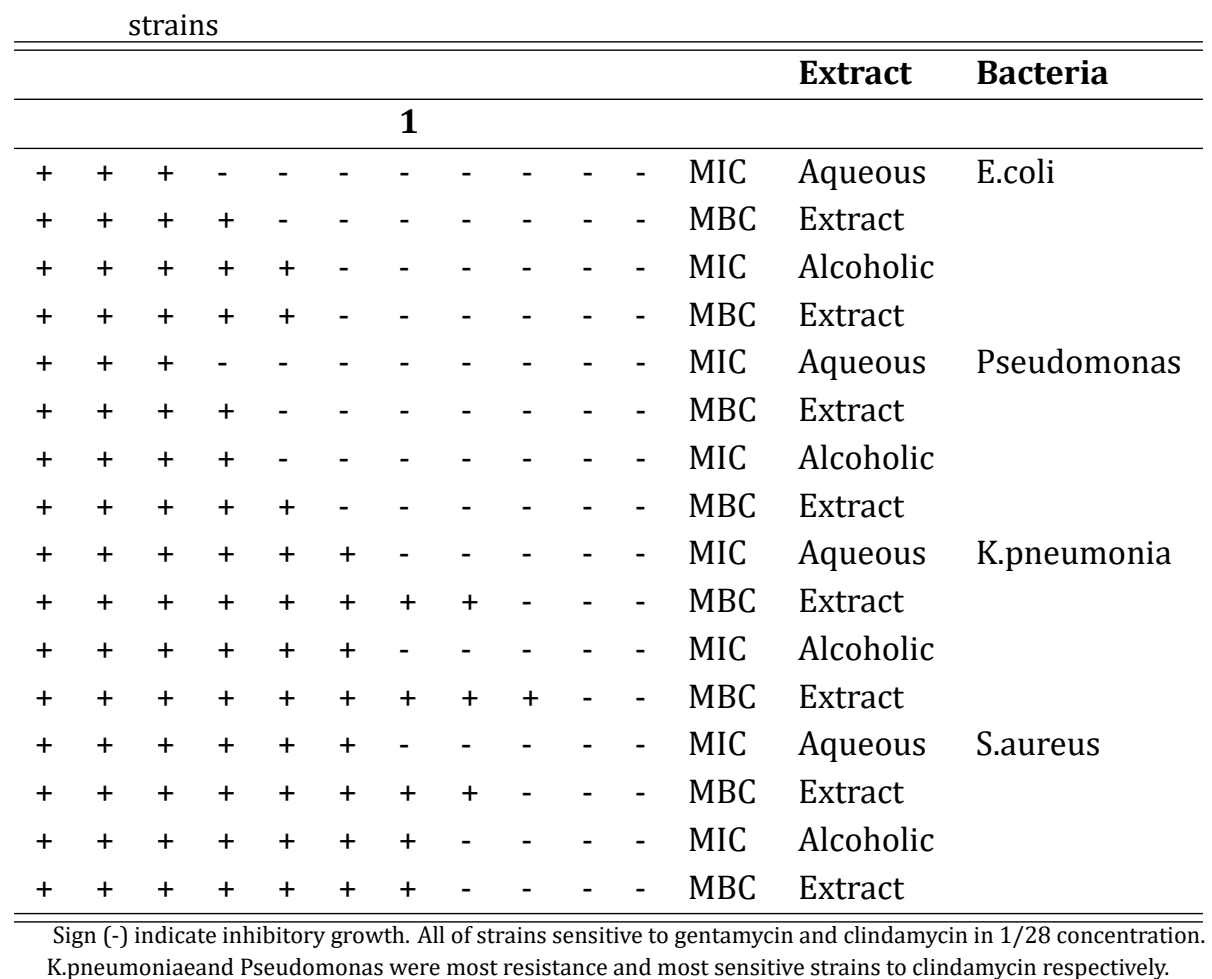

TABLE 4. MIC and MBC of aqueous and alcoholic green tea extracts on selected bacterial strains

\begin{tabular}{|c|c|c|c|c|c|c|c|c|c|c|c|}
\hline $0 / 5$ & 1 & $1 / 2$ & $1 /$ & $1 /$ & $1 / 1$ & $1 / 32$ & $1 / 6$ & $1 / 1$ & & & \\
\hline & & & 4 & 8 & 6 & & 4 & 28 & & & \\
\hline- & - & - & - & - & - & - & - & - & $\mathrm{MIC}$ & GM & E.coli \\
\hline- & - & - & - & - & - & - & - & - & MBC & & \\
\hline- & - & - & - & - & - & - & - & - & MIC & GM & Pseudomonas \\
\hline- & - & - & - & - & - & - & - & - & $\mathrm{MBC}$ & & \\
\hline- & - & - & - & - & - & - & - & - & MIC & GM & K.pneumonia \\
\hline- & - & - & - & - & - & - & - & - & MBC & & \\
\hline- & - & - & - & - & - & - & - & - & MIC & GM & S.aureus \\
\hline- & - & - & - & - & - & - & - & - & MBC & & \\
\hline+ & + & + & + & + & - & - & - & - & MIC & Clin & E.coli \\
\hline+ & + & + & + & + & + & - & - & - & MBC & & \\
\hline+ & + & + & + & + & + & + & - & - & $\mathrm{MIC}$ & Clin & Pseudomonas \\
\hline+ & + & + & + & + & + & + & + & - & $\mathrm{MBC}$ & & \\
\hline+ & + & + & + & - & - & - & - & - & $\mathrm{MIC}$ & Clin & K.pneumonia \\
\hline+ & + & + & + & + & + & - & - & - & MBC & & \\
\hline- & - & - & - & - & - & - & - & - & MIC & Clin & S.aureus \\
\hline- & - & - & - & - & - & - & - & - & $\mathrm{MBC}$ & & \\
\hline
\end{tabular}


$1: 128(512 \mathrm{mg} / \mathrm{ml})$ and their MBC178 was equal to $1: 64(512 \mathrm{mg} / \mathrm{ml})$. MIC and MBC results of alcoholic green tea extract for E.coli was 1:32 $(512 \mathrm{mg} / \mathrm{ml})$ and MIC for S.aureus equal to $1: 16(512 \mathrm{mg} / \mathrm{ml})$. E.coli and pseudomonas were most 180 sensitive strains to aqueous extract and K.pneumoniae was the most resistant strain in $512 \mu \mathrm{g} / \mathrm{ml} 181$ concentration. Among prepared extracts, ethanolic extract was shown the most effective on inhibition of all bacteria strains than aqueous extract. Table 4 shown different dilution of standard 183 antibiotic MIC and MBC against selected food born bacteria Antibacterial activity of green tea leaf extract against selected is demonstrated in Table 3. Results showed 177 that MIC of aqueous green tea extract for Pseudomonas and E.coliwas 1:128 $(512 \mathrm{mg} / \mathrm{ml})$ and their MBC 178 was equal to $1: 64(512 \mathrm{mg} / \mathrm{ml})$. MIC and MBC results of alcoholic green tea extract (512 mg/ml) and MIC for S.aureusequal to $1: 16(512 \mathrm{mg} / \mathrm{ml})$. E.coliand pseudomonas were most sensitive strains to aqueous extract and K.pneumoniaewas the most resistant strain in $512 \mu \mathrm{g} / \mathrm{ml}$ concentration. Among prepared extracts, ethanolic extract was shown the most effective oninhibition of all bacteria strains than aqueous extract. Table 4 shown different dilution of standard antibiotic MIC.

\section{DISCUSSION AND CONCLUSION}

Multiple drug resistant bacteria a major cause of failure of the public health. Evaluation of plants for antimicrobial property is the first step towards achieving the goal for developing eco-friendly management of infectious diseases of humans by the search for new bio-molecules of plant origin. Plants extract as a drug are effective, available, and cheap without side effects. Green tea was screened for antibacterial susceptibility against five human pathogenic food borne bacteria. A zone of inhibition and the antibacterial assays were evaluated medical effects of the extract against 218 these bacteria and results showed that green tea has major antibacterial activity. The results of this study indicate that green tea extract as a natural antimicrobial agent, has the potential power for preservation of the food from major foodborne bacteria and can be used for preserving various foodstuffs and antifungal or antibacterial therapy in medical. Both the aqueous and ethanolic extracts were effective against bacteria, but there is a considerable difference in the antimicrobial activity of the extract of green tea when the ethanol is the solvent and the extract when water is the solvent. Ethanolic extract of green tea was more effective as compared to aqueous extract. The $100 \%$ activity of green tea extract against bacteria was more than imipenem effective. We can note that the anti-bacterial activity of green tea extract is comparable to standard antibiotic. Our results indicate that the activity of aqueous and alcoholic extracts was comparable with gentamicin. This can be because of green tea phytochemicals compounds Moreover the properties of green tea, which inhibit bacterial Growth maybe related to their polyphenolic Components such as epicatechin, epicatechingallate, epigallocatechin, and epigallocatechingallate. All test organisms were inhibited by extract. The maximum zone of inhibition was observed against S. aureus (A Gram ositive organism) and the minimum was against pseudomonas (a Gram-negative organism). So that the Gram positive strain was more sensitive to green tea extract.We can see the variation in the size of the inhibition zone between different groups of bacteria. MICs varied widely (512 $\mu \mathrm{g}$ $/ \mathrm{ml}$ ) between different species. All strains were resistant to vancomycin while sensitive to green tea extract and inhibition zone showed approximately equal to that of gentamycin. Find new sources of natural compounds with antibacterial activity as our study result, useful for Control of infections acquired in hospitals and Communities caused by multi-drug resistant food borne bacteria in developing countries 


\section{Acknowledgment}

This survey is a part of a research project Soodabehalizadeh proposed to was supported by the Institute of technology-viravigene, Tehran, Iran. 244.

\section{REFERENCES}

1. Lucore LA, Cullison MA, Jaykus LA. Immobilization with metal hydroxides as a means to concentrate food-borne bacteria for detection by cultural and molecular methods. Applied \& Environmental Microbiology. 2000; 66(5): 1769-1776. DOI: $10.1128 / A E M .66 .5 .1769-1776.2000$

2. Mahboubi A, Kamalinejad M, Ayatollahi AM, Babaeian M. Total phenolic content and antibacterial activity of five plants of Labiatae against four foodborne and some other bacteria. Iranian Journal of Pharmaceutical Research. 2014; 13(2): 559-566.

3. Sandigawad BM, Patil CG. The in vitro antibacterial activity of cinnamomum species A. Asian Journal of Expermental Biological Science. 2010; 1(2): 434-439.

4. Lewus CB, Kaiser A, Montville TJ. Inhibition of food-borne bacterial pathogens by bacteriocins from lactic acid bacteria isolated from meat. Applied \& Environmental Microbiology. 1991; 57(6): 1683-1688.

5. Santiesteban-López A, Palou E, López-Malo A. Susceptibility of food-borne bacteria to binary combinations of antimicrobials at selected aw and pH. Journal of Applied Microbiology. 2007; 102(2): 486-497.

DOI: $10.1111 /$ j.1365-2672.2006.03092.x

6. Xu W, Qu W, Huang K, Guo F, Yang J, Zhao H, Luo Y. Antibacterial effect of grapefruit seed extract on food-borne pathogens and its application in the preservation of minimally processed vegetables. Postharvest Biology \& Technology. 2007; 45(1): 126-133. DOI: 10.1016/j.postharvbio.2006.11.019

7. Ahmadian-Attari MM, Monsef Esfahani HR, Amin GR, Fazeli MR, Jamalifar H, Kamalinia G, Farsam H. The ethno pharmacological study on antibacterial activity of some selected plants used in Iranian traditional medicine. Journal of Medicinal Plants. 2009; 3(31): 50-57.

8. Reich E, Schibli A, Widmer V, Jorns R, Wolfram E, DeBatt A. HPTLC methods for identification of green tea and green tea extract. Journal of Liquid Chromatography \& Related Technologies. 2006; 29(14): 2141-2151.

DOI: $10.1080 / 15512160600760293$

9. Dwyer JT, Peterson J. Tea and flavonoids: Where we are, where to go next. The American Journal of Clinical Nutrition. 2013; 98(6): 1611S-1618S. DOI: 10.3945/ajcn.113.059584

10. Cabrera C, Artacho R, Giménez R. Beneficial effects of green tea-A review. Journal of the American College of Nutrition. 2006; 25(2): 79-99. DOI: 10.1080/07315724.2006.10719518

11. Mazzanti G, Menniti-Ippolito F, Moro PA, Cassetti F, Raschetti R, Santuccio C, Mastrangelo S. Hepatotoxicity from green tea: A review of the literature and two unpublished cases. European Journal of Clinical Pharmacology. 2009; 65(4): 331-341. DOI: $10.1007 /$ s00228-008-0610-7

12. Boehm K, Borrelli F, Ernst E, Habacher G, Hung SK, Milazzo S, Horneber M. Green tea (Camellia sinensis) for the prevention of cancer. Cochrane Database Systematic Review. 2009; 3(3). DOI: 10.1002/14651858.CD005004.pub2

13. Taguri T, Tanaka T, Kouno I. Antimicrobial activity of 10 different plant polyphenols against bacteria causing food-borne disease. Biological \& Pharmaceutical Bulletin. 2004; 27(12): 1965-1969. D0I: 10.1248/bpb.27.1965

14. Ferraro MJ. Methods for dilution antimicrobial susceptibility tests for bacteria that grow aerobically. Clinical and Laboratory Standards Institute. 2000; 32(2): 1-68.

— This article does not have any appendix. - 